\title{
Huancabamba rotundiceps Linnavuori (Homoptera, Cicadellidae, Deltocephalinae): descrição da fêmea ${ }^{1}$
}

\author{
Keti Maria Rocha Zanol ${ }^{2}$
}

\begin{abstract}
Huancabamba rotundiceps Linnavuori (Homoptera, Cicadellidae, Deltocephalinae): description of the female. The female of Huancabamba rotundiceps is described. Illustrations of male genitalia is also added.

KEY WORDS. Homoptera, Cicadellidae, Deltocephalinae, Huancabamba rotundiceps, female
\end{abstract}

LINNAVUORI (1959) descreveu o gênero e espécie, Huancabamba rotundiceps com base em exemplares machos provenientes do Peru. LINNAVUORI \& DELONG (1977) ao estudarem a fauna chilena incluíram o gênero Huancabamba na chave dos gêneros que compõem o grupo Yungasia. Neste trabalho, apresenta-se a descrição da fêmea de Huancabamba rotundiceps Linnavuori e também ilustrações da genitália do macho.

$\mathrm{O}$ material examinado pertence as seguintes Instituições: AMNH - American Museum of Natural History, New York, CASC - California Academy of Science, San Francisco; DZUP - Coleção de Entomologia Pe J.S.Moure, Curitiba, Paraná.

\section{Huancabamba rotundiceps Linnavuori, 1959}

Figs 1-4

Huancabamba rotundiceps Linnavuori, 1959: 204 (ilustração), 205 (descrição), Localidade-tipo: Huancabamba, Peru. - Linnavuori \& DeLong, 1977: 204 (chave).

Fêmea. Externamente semelhante ao macho, com coloração geral amarelada. Coroa marfim com quatro manchas marrom-claras e arredondadas na margem anterior; região discal com nuanças amarelas e uma faixa transversa, entre as suturas frontoclipeais, junto à sutura coronal marrom. Frontoclípeo com arcos laterais marrom-claros. Anteclípeo com uma mancha arredondada marrom-clara. Genas com uma mancha embaixo dos alvéolos antenais marrom-clara. Pronoto amarelo; margem anterior marfim com manchas marrons. Tégminas semitransparentes, com áreas esbranquiçadas; células com inúmeros pontos formando manchas irregulares marrons; célula anteapical central, segunda célula discal, segunda e terceira células apicais marrom-claras. Venação amarela.

1) Contribuição número 1078 do Departamento de Zoologia, Universidade Federal do Paraná.

2) Departamento do Zoologia, Universidade Federal do Paraná. Caixa Postal 19020, 81531-990 Curitiba, Paraná, Brasil. Bolsista do CNPq. 


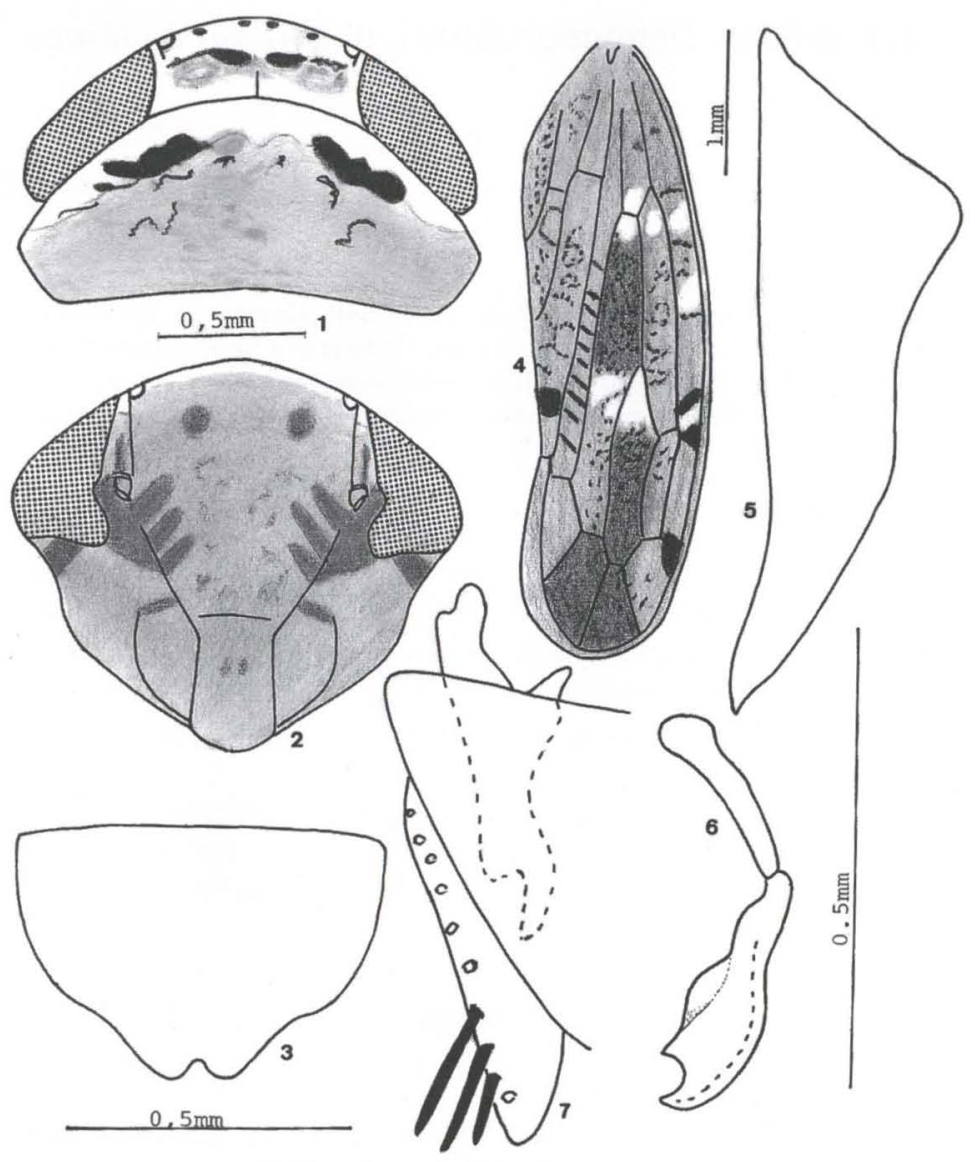

Figs 1-7. Huancabamba rotundiceps. (1-4) Fêmea: (1) cabeça e pronoto, dorsal; (2) face; (3) sétimo esternito; (4) tégmina. (5-7) Genitália do macho: (5) pigóforo, lateral; (6) edeago, lateral; (7) valva, placa subgenital e estilo.

Cabeça tão larga quanto o pronoto. Coroa mais longa medianamente do que junto aos olhos. Região discal lisa. Sutura coronal não atingindo a metade do comprimento da coroa. Ocelos visíveis de cima. Distância ocelo-ocular menor que o diâmetro dos ocelos. Olhos, em vista ventral, com emarginação omatidial. Sutura frontoclipeal estendendo-se além dos ocelos. Anteclípeo mais largo no ápice; superfície plana.

Pronoto com superfície lisa. Tégminas com falsas veias e duas células anteapicais fechadas. Margem costal com veias extranumerárias. Primeira célula 
discal longa, alcançando a célula anteapical externa. Veia transversa s-m após a bifurcação da S; veia transversa s presente. Apêndice curto, não alcançando M3+4. Espinulação das tíbias anteriores $3+4$. mediana.

Sétimo esternito com a margem posterior sinuosa e uma pequena fenda

Macho. Genitália: figuras 5-7.

Comprimento total. Macho: 4,70-5,00mm, fêmea: 4,70-5,00mm.

Material examinado. PERU: Huancabamba, 8.13.45, P.A Berry Lot 46-1503, S.A Poi Lab, No 1316-4; Paratype R. Linnavuori Huancabamba rotundiceps, 1 macho (AMNH); Chancay river Valley, III.15.51, Ross and Michelbacker collectors, 1 macho; Ibidem, III.25.51, 1 macho; Callao, XI.16.50, Michelbacher and Ross Collectors, 1 macho, 1 fêmea (AMNH); $10 \mathrm{~km} \mathrm{~N}$. of Barranca, III.15.51, Ross and Michelbacher collectors, 2 machos (CASC, DZUP); Ibidem, III.22.31, 1 macho (DZUP).

Variação intraespecífica. A tégmina direita pode apresentar uma veia extranumerária entre $1 \mathrm{~A}$ e a sutura claval enquanto que a tégmina esquerda pode apresentar uma veia extranumerária entre $1 \mathrm{~A}$ e a sutura e outra entre as anais.

\section{REFERÊNCIAS BIBLIOGRÁFICAS}

LINNAVUORI, R. 1959. Revision of the neotropical Deltocephalinae and some related subfamilies (Homoptera). Ann. Zool. Soc. Vanamo 20 (1): 1-370.

LinNAvUori, R. \& D. M. DeLong. 1977. The leafhoppers (Homoptera: Cicadellidae) known from Chile. Brenesia 12-13: 163-267.

Recebido em 20.VIII.1998; aceito em 11.X.1999. 